\title{
EVALUATION OF BIOACTIVE COMPOUNDS, ANTIOXIDANT, AND ANTIBACTERIAL PROPERTIES OF MEDICINAL PLANTS SAUROPUS ANDROGYNUS L. AND ERYTHRINA VARIEGATA L.
}

\author{
LAVEENA KB, CHANDRA M* \\ Department of Postgraduate Studies and Research in Biosciences, Mangalore University, Mangalagangothri, Karnataka, India. \\ Email: drchandram1@gmail.com
}

Received: 30 June 2018, Revised and Accepted: 04 August 2018

\section{ABSTRACT}

Objectives: The aim of the present study was to evaluate the bioactive, antioxidant, and antibacterial activity of methanolic extracts of medicinal plants Erythrina variegata L., and Sauropus androgynus L.

Methods: Total phenolic, flavonoid, tannin content, total antioxidant capacity, 1, 1diphenyl-2-picryl hydrazyl radical scavenging activity, and reducing power assay of the extracts were determined by spectrophotometric methods.

Results: Total phenolic, flavonoid, and tannin content was more in E. variegata compared to S. androgynus, and the alkaloid, saponin, and carotenoid content was high in $S$. androgynus. The overall antioxidant activity of $S$. androgynus was found to be higher than $E$. variegata. Antibacterial activities of the selected plants were studied against human pathogenic organisms, namely Escherichia coli and Staphylococcus aureus.

Conclusions: The present study reveals that the selected plants would exert several beneficial effects by virtue of their natural antioxidant activity; further characterization of the phenolic composition is needed and could be harnessed as drug formulation.

Keywords: Antibacterial, Antioxidant, Bioactive, 1, 1diphenyl-2-picryl hydrazyl scavenging activity, Medicinal plants, Reducing power assay.

(C) 2018 The Authors. Published by Innovare Academic Sciences Pvt Ltd. This is an open access article under the CC BY license (http://creativecommons. org/licenses/by/4. 0/) DOI: http://dx.doi.org/10.22159/ajpcr.2018.v11i12.28207

\section{INTRODUCTION}

Free radicals are fundamental to any biochemical process and represent an essential part of aerobic life and metabolism [1]. The most common reactive oxygen species (ROS) include superoxide $\left(\mathrm{O}_{2}^{-}\right)$anion, hydrogen peroxide, Peroxyl radicals, and reactive hydroxyl $\left(\mathrm{OH}^{\circ}\right)$ radicals. The nitrogen derived free radicals are nitric oxide ( $\mathrm{NO}^{\circ}$ ) and peroxynitrite anion. Majority of the diseases/disorders are mainly linked to oxidative stress produced due to free radicals [2]. ROS have been implicated in over a hundreds of disease states which range from arthritis, connective tissue disorders to carcinogenesis, aging, physical injury, infection, and acquired immunodeficiency syndrome [3]. Oxidative process is one of the most important routes for producing free radicals in foods, drugs, and even in living systems [4]. Herbal drugs containing free radical scavengers are known for their therapeutic activity [5]. Among the numerous naturally occurring antioxidants; ascorbic acid, carotenoids, flavonoids, and phenolic compounds are more effective [6]. They are known to inhibit lipid peroxidation (by inactivating lipoxygenase), to scavenge free radicals and active oxygen species by propagating a reaction cycle and to chelate heavy metal ions [7]. Medicinal plants are delivering new drugs and many of the modern medicine indirectly, and these medicinal plants have organized by refined traditional medicine practices that have been used for 1000 of years by people in the world. Since the past few decades, researchers have more attention on medicinal plants, screening for their biological and pharmaceutical properties of the medicinal plants $[8,9]$. Medicinal plants are considered as clinically effective and safer alternatives to the synthetic antibiotics [10]. Plants produce a very impressive array of antioxidant compounds that include carotenoids, flavonoids, and tannins to prevent the oxidation of the susceptible substrate [11]. Phenolic compounds with antioxidant activity, which are widely distributed in many fruits, vegetables, and tea, are believed to account mainly for the antioxidant capacity of many plants [12-14]. Natural antioxidants have become the target of a great number of research studies in finding the sources of potentially safe, effective, and cheap antioxidants [15]. Hence, the present study was made to analyze the phytochemicals, bioactive compounds, antioxidants, and reducing power assay and also antibacterial properties of medicinal plants, namely Sauropus androgynus L., and Erythrina variegata L. against Escherichia coli and Staphylococcus aureus.

\section{METHODS}

Plant materials used

The medicinal plants such as E. variegata L. and S. androgynus L. were collected from in and around area of Mangalore and Belthangady (Western Ghats of Karnataka). The plants were identified and authenticated by Dr. SharathChandra, Assistant Professor, Department of Botany, Canara College, Mangalore, Karnataka, India.

\section{Microbial strains}

Bacterial pathogens such as E. coli (MTCC 40) and S. aureus (MTCC 86) were obtained from the Institute of Microbial Technology, Chandigarh, India. The bacterial cultures were inoculated in nutrient broth for $18 \mathrm{~h}$, and the suspensions were serially diluted to get approximately $10^{-5}$ dilution.

\section{Preparation of plant extract}

The leaf samples were separated from each plant and were washed with running tap water, surface sterilized in distilled water, blot it dried and powdered. Different solvents, namely aqueous, hexane, ethanol, and methanol were used for the extraction of leaf materials. The extraction was carried out using Soxhlet apparatus. The extracts obtained from solvents were concentrated using rotary vacuum evaporator and then dried. The extract thus obtained was used for various analysis.

\section{Qualitative phytochemical screening}

Phytochemical screening was carried out for the leaf extracts as per the standard methods $[16,17]$. 


\section{Bioactive compounds}

\section{Determination of total phenolic}

The total phenolic content was determined using Folin-Ciocalteu (FC) method [18]. $0.1 \mathrm{ml}$ of sample was made up to $0.25 \mathrm{ml}$ with distilled water and mixed with $0.25 \mathrm{ml}$ of FC phenol reagent. After $3 \mathrm{~min}, 0.5 \mathrm{ml}$ of $20 \%$ sodium carbonate solution was added to the mixture and made up to $5 \mathrm{ml}$ by adding distilled water. The resultant mixture was kept in the dark for $30 \mathrm{~min}$, after which its absorbance was read at $760 \mathrm{~nm}$. The results were expressed as $\mu \mathrm{g}$ of Gallic acid equivalents/mg of extract.

\section{Determination of total flavonoids}

$0.5 \mathrm{ml}$ of the sample was mixed with $1.5 \mathrm{ml}$ methanol, $0.1 \mathrm{ml}$ of $10 \%$ $\mathrm{AlCl}_{3}, 0.1 \mathrm{ml}$ of $1 \mathrm{M}$ potassium acetate and $2.8 \mathrm{ml}$ of distilled water. After incubation at room temperature for $30 \mathrm{~min}$, the absorbance of the reaction mixture was measured at $415 \mathrm{~nm}$. The amount of flavonoid content was expressed as $(\mu \mathrm{g})$ equivalents of quercetin/mg of sample [19].

\section{Determination of tannin}

The tannin content was estimated by the method [20] with slight modifications. $20 \mu \mathrm{l}$ of the sample was aliquoted into a test tube containing $980 \mu \mathrm{l}$ of distilled water. To this, $500 \mu \mathrm{l}$ of $1 \% \mathrm{~K}_{3} \mathrm{Fe}(\mathrm{CN}){ }_{6}$ and $100 \mu \mathrm{l}$ of $1 \%$ ferric chloride $\left(\mathrm{FeCl}_{3}\right)$ were added and made up to $3 \mathrm{ml}$ with distilled water. After $10 \mathrm{~min}$, the reaction mixture was measured using a UV spectrophotometer at $720 \mathrm{~nm}$. The tannin content was expressed as $\mu \mathrm{g}$ of tannic acid equivalents/mg of extract.

\section{Determination of alkaloid}

To $2.5 \mathrm{~g}$ of sample, $200 \mathrm{ml}$ of $10 \%$ acetic acid in ethanol was added and covered with aluminum foil. Then, the reaction mixture was allowed to stand for $4 \mathrm{~h}$. The extract was concentrated on a water bath to one-quarter of the original volume after filtration. To this extract, concentrated ammonium hydroxide was added dropwise until the precipitation was complete. Then, the precipitation was collected, washed with dilute ammonium hydroxide and filtered. The residue was the alkaloid, which was dried and weighed [21].

The alkaloid content was determined using the following formula:

Percentage of alkaloid $=$ (final weight of the sample/initial weight of the extract) $\times 100$

\section{Saponin determination}

Saponin content was determined with slight modification [22]. $20 \mathrm{~g}$ of sample was dispersed in $200 \mathrm{ml}$ of $20 \%$ ethanol, and the suspension was heated over a hot water bath for $4 \mathrm{~h}$ with continuous stirring at about $55^{\circ} \mathrm{C}$. The mixture was filtered, and the residue was re-extracted with another $200 \mathrm{ml}$ of $20 \%$ ethanol. The combined extracts were reduced to $40 \mathrm{ml}$ over water bath at about $90^{\circ} \mathrm{C}$. The concentrate was transferred into a $250 \mathrm{ml}$ separating funnel, and $20 \mathrm{ml}$ of diethyl ether was added and shaken vigorously. The aqueous layer was recovered while the ether layer was discarded. The purification process was repeated twice. To the aqueous layer, $60 \mathrm{ml}$ of $\mathrm{n}$-butanol was added, and combined n-butanol extracts were washed twice with $10 \mathrm{ml}$ of $5 \%$ aqueous sodium chloride. After discarding the sodium chloride layer, the remaining solution was heated in a water bath for $30 \mathrm{~min}$, after which the solution was transferred into a crucible and was dried in a hot air oven to a constant weight. The saponin content was calculated in percentage.

\section{Determination of $\boldsymbol{\beta}$-Carotene}

$100 \mathrm{mg}$ of each plant extracts were dissolved in $10 \mathrm{ml}$ of acetone:hexane mixture (4:6) and centrifuged at $6000 \mathrm{rpm}$ for $3 \mathrm{~min}$. The 0 . D of the filtrate was read at 453,505, and $663 \mathrm{~nm}$. The assay was carried out in triplicates. The results were mean \pm standard deviation and expressed as $\mu \mathrm{g}$ of carotenoid/g of extract [23].

\section{Total antioxidant capacity}

The total antioxidant capacity was determined by the method [24]. The methanol extract was added into a series of test tubes containing methanol and mixed with $2 \mathrm{ml}$ of phosphomolybdenum reagent solution. Then, the tubes were kept in a water bath for $90 \mathrm{~min}$ at $95^{\circ} \mathrm{C}$. The resultant mixture was cooled to room temperature, and the absorbance was read at $695 \mathrm{~nm}$ against blank. The experiment was conducted in triplicates and values were expressed as equivalents of ascorbic acid (mg)/g of the sample.

\section{1, 1diphenyl-2-picryl hydrazyl (DPPH) radical scavenging assay} DPPH free radical scavenging assay was measured by the method [25]. Various concentrations $(20-100 \mu \mathrm{g} / \mathrm{ml})$ of a leaf extract $(2 \mathrm{ml})$ were taken in a number of vials containing $3 \mathrm{ml}$ of $0.1 \mathrm{mM}$ methanolic solution of DPPH. The test tubes were shaken gently and kept aside for $30 \mathrm{~min}$ at room temperature in the dark. An optical density of the sample was measured at $517 \mathrm{~nm}$ against blank. Ascorbic acid was used as the standard control. All the tests were performed in triplicates.

Free radical scavenging activity was expressed as inhibition percentage and was calculated using the following formula:

\section{(O. D of Control -}

Percentage inhibition $(\%)=\frac{\text { O. D of Sample) }}{\text { O. D of Control }} \times 100$

\section{Reducing power assay}

Different concentrations of the extract were prepared in methanol solvent and assorted with $2.5 \mathrm{ml}$ of $0.2 \mathrm{M}$ phosphate buffer followed by $2.5 \mathrm{ml}$ of freshly prepared $1 \%$ potassium Ferricyanide $\left(\mathrm{K}_{3} \mathrm{Fe}\left(\mathrm{CN}_{6}\right)\right)$. This mixture was incubated for $20 \mathrm{~min}$ at $50{ }^{\circ} \mathrm{C}$. To this, $2.5 \mathrm{ml}$ of $10 \%$ Trichloroacetic acid was added and centrifuged at $3000 \mathrm{rpm}$ for $10 \mathrm{~min}$. $2.5 \mathrm{ml}$ of the clear extract was assorted with $2.5 \mathrm{ml}$ of methanol and $0.5 \mathrm{ml}$ of $0.1 \% \mathrm{FeCl}_{3}$. The absorbance was measured at $700 \mathrm{~nm}$. The experiment was conducted in triplicates, and the reducing power was expressed as (mg) equivalents of ascorbic acid/g of the extract [26].

\section{Antibacterial activity}

\section{Agar well diffusion assay}

The antimicrobial activity was measured by agar well diffusion assay [27]. The plant extracts were allowed to diffuse out into the medium and to interact in a plate freshly seeded with the test organisms. Petri plates containing $15 \mathrm{ml}$ of nutrient agar medium were seeded with the bacterial strains. Each labeled medium plate was uniformly inoculated with a test organism using a sterile cotton swab. Wells were punchered, and 25, 50, 75 , and $100 \mu \mathrm{l}$ of the methanolic plant extracts were added. The plates were then incubated at $37^{\circ} \mathrm{C}$ for $24 \mathrm{~h}$. Ampilox and Chloramphenicol $(0.05 \%$ each) were used as positive control and analysis was done in triplicates. The antibacterial activity was assayed by measuring the diameter of the inhibition zone formed around the well. The diameter of the zone of inhibition was measured in millimeters [28].

\section{Determination of minimum inhibitory concentration (MIC)}

MIC is usually considered as the most basic laboratory measurement of the activity of antimicrobial agent against microorganisms. The MIC was determined using a methanolic extract of plants (S. androgynus L. and E. variegata L.) which inhibits the visible growth of microorganisms. Different dilutions (10-100\%) of the plant extracts were assayed against the test organisms. The tubes were incubated at $37^{\circ} \mathrm{C}$ for $24 \mathrm{~h}$. Distilled water was used as negative control. After incubation, MIC of each sample was determined by reading the optical density at $600 \mathrm{~nm}$ in UV spectrophotometer. The MIC was defined as the lowest concentration able to inhibit any visible bacterial growth [29].

\section{Statistical analysis}

The experimental results were expressed as mean \pm standard error means (SEM) of triplicates. Analysis of data was carried out by applying one-way analysis of variance (Software-Minitab 17). p-value $<0.05$ $(\mathrm{p}<0.05)$ was considered as statistically significant.

\section{RESULTS}

Qualitative phytochemical analysis revealed that all the aqueous, ethanolic, and methanolic leaf extracts showed the presence of carbohydrates, proteins, amino acids, glycosides, phenols, tannins, flavonoids, alkaloids, cardiac glycosides, saponins, and terpenoids with 
Table 1: Qualitative analysis of phytochemicals in S. androgynus $\mathrm{L}$. and E. variegata $\mathrm{L}$.

\begin{tabular}{|c|c|c|c|c|c|c|}
\hline \multirow[t]{2}{*}{ Tests } & \multicolumn{3}{|c|}{ S. androgynus L. } & \multicolumn{3}{|c|}{ E. variegata L. } \\
\hline & Aqueous & Ethanol & Methanol & Aqueous & Ethanol & Methanol \\
\hline Carbohydrate & + & + & + & + & + & + \\
\hline Protein & + & + & + & + & + & + \\
\hline Amino acids & + & + & + & + & + & + \\
\hline Alkaloids & + & + & + & + & + & + \\
\hline Saponins & + & + & + & + & + & + \\
\hline Phenols & + & + & + & + & + & + \\
\hline Phytosterols & + & + & + & + & + & + \\
\hline Flavonoids & + & + & + & + & + & + \\
\hline Glycosides & + & + & + & - & - & - \\
\hline Terpenoids & - & - & - & + & + & + \\
\hline Tannins & + & + & + & + & + & + \\
\hline
\end{tabular}

+: Present, -: Absent. S.androgynus: Sauropus androgynus, E.variegata: Erythrina variegata, SEM: Standard error of the mean

Table 2: Quantitative analysis of phytochemicals in S. androgynus L. and E. variegata $\mathrm{L}$.

\begin{tabular}{lll}
\hline Phytoconstituents & S. androgynus $\mathbf{L}$. & E. variegata $\mathbf{L}$. \\
\hline Total phenolic (mg GAE/g) & $276.86 \pm 0.49$ & $310.86 \pm 0.49$ \\
Total flavonoid (mg QE/g) & $148.94 \pm 0.05$ & $214.86 \pm 0.27$ \\
Tannin content (mg TAE/g) & $28.51 \pm 0.17$ & $31.44 \pm 0.8$ \\
Alkaloid content (mg/g) & $6.609 \pm 0.002$ & $5.70 \pm 0.124$ \\
Saponin content (mg/g) & $20.067 \pm 0.028$ & $15.08 \pm 0.038$ \\
$\beta$-carotene content (mg/g) & $304 \pm 0.005$ & $213.7 \pm 0.0003$ \\
\hline
\end{tabular}

Values are expressed as mean \pm SEM, $n=3, P<0.05$ considered as significant.

SEM: Standard error of the mean. S.androgynus: Sauropus androgynus,

E.variegata: Erythrina variegata

variations in different solvents in both the plant extracts. Negative results were recorded for terpenoids in $S$. androgynus and glycosides in $E$. variegata leaf extracts (Table 1). The presence of these bioactive compounds in the leaf extracts encourages antioxidant studies.

The results of the quantitative analysis of total phenolic, flavonoid, tannin, alkaloid, and saponin content were represented in Table 2. Total phenol contents were found high (310.86 mg) in E. variegata and low (276.86 mg) in S. androgynus. E. variegata showed a higher amount of flavonoid content (214.86 mg) and lower (148.94 mg) in S. androgynus. Tannin content was $31.44 \mathrm{mg}$ in E. variegata and $28.51 \mathrm{mg}$ in $S$. androgynus. The total alkaloid and saponin content in E. variegata were $5.79 \mathrm{mg}$, and $15.08 \mathrm{mg}$ and S. androgynus was $6.609 \mathrm{mg}$ and $20.05 \mathrm{mg}$, respectively. $\beta$ - Carotene content was found to be $304 \mathrm{mg}$ in S. androgynus and $213.7 \mathrm{mg}$ in E. variegata.

The total antioxidant activity was found high $(250.55 \mu \mathrm{g} / \mathrm{mg})$ in S. androgynus and low $(82.95 \mu \mathrm{g} / \mathrm{mg})$ in E. variegata. In DPPH free radical scavenging activity, the results were expressed in terms of percentage of inhibition (\%). S. androgynus leaf extract showed strong inhibition of DPPH radical (45.38\%) followed by leaf extract of $E$. variegata $(4.08 \%)$. Percentage inhibition for the standard ascorbic acid was found to be $58.4 \%$. A freshly prepared DPPH solution exhibits a deep purple color with an absorption maximum at $517 \mathrm{~nm}$. Reducing power assay of leaf extract of E. variegata was $150.07 \mu \mathrm{g} / \mathrm{mg}$ and $132.91 \mu \mathrm{g} /$ $\mathrm{mg}$ in $S$. androgynus. Reducing power assay of two medicinal plants was expressed as $(\mu \mathrm{g})$ equivalents of ascorbic acid/mg of the extract. The extracts possibly contain a different type of phenolic compounds, which have different antioxidant capacities (Table 3).

Antibacterial activity of methanolic leaf extracts of $S$. androgynus was investigated against two bacterial strains, namely S. aureus and E. coli. Methanolic extract of $S$. androgynus was active against S. aureus (Grampositive) and E. coli (Gram-negative) when compared to the leaf extract of $E$. variegata. Table 4 summarizes the microbial growth inhibition of methanolic leaf extract of plants and their MIC. S. androgynus was found to be the most potent against microbes showing $19.48 \mathrm{~mm}$ and
$17.68 \mathrm{~mm}$ while E. variegata showed $17.49 \mathrm{~mm}$ and $16.2 \mathrm{~mm}$ zone of inhibition against $S$. aureus and E. coli. S. androgynus was found to inhibit S. aureus at a concentration of $10 \%$ and E. coli $20 \%$. E. variegata was found to inhibit at $10 \%$ concentration in both S. aureus and E.coli. Presence of flavonoids and tannins in plants may be responsible for antibacterial activity.

\section{DISCUSSION}

The medicinal value of plants lies in some chemical substances that have a definite physiological action on the human body. Different phytochemicals have been found to possess a wide range of activities, which may help in protection against chronic diseases. For example, alkaloids protect against chronic diseases. Saponins protect against hypercholesterolemia and antibiotic properties. Steroids and triterpenoids show the analgesic properties [30]. Alkaloid contents were studied in 12 leafy vegetables which are capable of reducing headaches associated with hypertension [31]. Many authors have described the potential antioxidant properties of polyphenols. These compounds act as antioxidants by donation of hydrogen atom, as an acceptor of free radicals, by interrupting chain oxidation reactions or by chelating metals [32,33]. Tannins comprise both condensed non-hydrolysable tannins, known as proanthocyanidins, and esters of gallic acid and ellagic acid defined as hydrolysable tannins $[34,35]$. The decrease in absorbance of $\beta$-carotene in the presence of different extracts due to the oxidation of $\beta$-carotene and linoleic acid [36]. Antioxidants have already been found in plant materials and supplements. Due to their natural origin, the antioxidants obtained from plants are of greater benefit in comparison to synthetic ones. The use of natural antioxidants from plants does not induce side effects, while synthetic antioxidants were found to have genotoxic effect [37-40]. It has been recognized that flavonoids show antioxidant activity and their effects on human nutrition and health are considerable. The mechanisms of action of flavonoids are through scavenging or chelating process [41,42]. Phosphomolybdenum method is based on the reduction Mo (VI) to Mo (V) by the sample analyte and subsequent formation of green phosphate/ Mo (V) complex at acidic pH. Antioxidant activity may be probably due to phenolic compounds present in the extract. Free radicals are involved in many disorders such as neurodegenerative diseases, cancer, and AIDS. Antioxidants through their scavenging power are useful for the management of those diseases. Stable free radical method is an easy, rapid and sensitive way to survey the antioxidant activity of a specific compound or plant extracts [43]. It is known that only flavonoids with a certain structure and particularly $\mathrm{OH}^{\circ}$ position in the molecule can act as proton donating and show radical scavenging activity $[44,45]$. DPPH solution exhibits purple color generally fades when antioxidant molecules quench DPPH free radicals (i.e., by providing hydrogen atoms or by electron donation, conceivably through a free-radical attack on the DPPH molecule) and convert them into a colorless-/bleached product (i.e., 2,2-diphenyl-1-hydrazine, or a substituted analogous hydrazine), resulting in a decrease in absorbance at $517 \mathrm{~nm}$ band [46]. The reducing 
Table 3: Antioxidant activity of S. androgynus and E. variegata leaf extracts

\begin{tabular}{llll}
\hline Medicinal plants & $\begin{array}{l}\text { Total antioxidant } \\
\text { activity }(\boldsymbol{\mu g} / \mathbf{m g})\end{array}$ & $\begin{array}{l}\text { Reducing power } \\
\text { assay }(\boldsymbol{\mu g} / \mathbf{m g})\end{array}$ & $\begin{array}{l}\text { DPPH radical } \\
\text { scavenging activity }(\%)\end{array}$ \\
\hline S. androgynus & $250.55 \pm 0.49$ & $132.91 \pm 0.03$ & 45.38 \\
E. variegata & $82.95 \pm 0.56$ & $150.07 \pm 0.04$ & 4.08 \\
\hline
\end{tabular}

S.androgynus: Sauropus androgynus, E.variegata: Erythrina variegata, DPPH: 1, 1diphenyl-2-picryl hydrazyl, SEM: Standard error of the mean

Table 4: Antibacterial activity of $S$. androgynus and E. variegata plant extracts

\begin{tabular}{lllll}
\hline Plant & \multicolumn{1}{l}{ S. aureus } & & E. coli \\
\cline { 2 - 5 } & Zone of Inhibition $\mathbf{( m m )}$ & MIC & Zone of Inhibition (mm) & MIC \\
\hline S. androgynus & $19.48 \pm 0.02$ & $10 \%$ & $17.68 \pm 0.15$ & $20 \%$ \\
E. variegate & $17.49 \pm 0.01$ & $10 \%$ & $16.2 \pm 0.2$ & $10 \%$ \\
Control Ampilox & $24.2 \pm 0.2$ & $-N A-$ & $22.13 \pm 0.11$ & - NA- \\
Chloramphenicol & $22.2 \pm 0.01$ & $-N A-$ & $21.7 \pm 0.11$ & - NA- \\
\hline
\end{tabular}

Data expressed as mean \pm SEM, $\mathrm{P}<0.05$ considered as significant, $-\mathrm{NA}$ : Not applicable. S.androgynus: Sauropus androgynus, E.variegata: Erythrina variegata,

MIC: Minimum inhibitory concentration

power capacity of the extract may serve as a significant indicator of its potential antioxidant activity. The antioxidant activity of extracts could not be explained just on the basis of their phenolic content but also required their proper characterization [47]. The antibacterial activities of medicinal plants are attributed due to the presence of flavonoids, tannins, and steroidal alkaloids [48]. Plants are a major key source of drug or treatment approach in different traditional medicinal systems. A large number of people believe in herbal based medicines for basic health-care requirements $[49,50]$. Phytochemical studies revealed the presence of phenolics, flavonoids, and tannins which contributes to the antimicrobial activity of these plants. In recent years, multiple drug resistance in human pathogenic microorganisms has developed due to the indiscriminate use of commercial antimicrobial drugs commonly used in the treatment of infectious diseases, making it a global growing problem. In addition to this problem, antibiotics are sometimes associated with adverse effects on host including hypersensitivity, immune suppression, and allergic reactions [51]. Therefore, there is a need to develop alternative antimicrobial drugs for the treatment of infections obtained from various sources such as medicinal plants. The antibacterial activity found in this present study may be attributed to the presence of secondary metabolites of various chemical types present in the plant material either individually.

\section{CONCLUSION}

Results of our study suggest that the great value of the species S. androgynus and E. variegata for use in pharmacy and phytotherapy. Based on this information, it could be concluded that the plants are natural sources of antioxidant substances of high importance. The highest concentration of phenolic compounds was obtained in the plant extracts using solvents of high polarity; the methanolic extract manifested greater power of extraction from S. androgynus and E. variegata. Further studies of these plant species should be directed to carry out in vivo studies of its medicinal active components to prepare natural pharmaceutical products of high value.

\section{ACKNOWLEDGMENT}

The authors are thankful to the Department of Biosciences, Mangalore University, Mangalagangothri, Karnataka, India, for providing laboratory facilities to carry out the work.

\section{AUTHOR'S CONTRIBUTIONS}

Laveena $\mathrm{K}$ B conducted the experiments and also prepared the manuscript. Dr. Chandra $M$ was involved in planning of the experimental work and assisting in the manuscript preparation and data interpretation. The manuscript of the study and revision was done by both the authors.

\section{CONFLICTS OF INTEREST}

The authors declare that they have no conflicts of interest.

\section{REFERENCES}

1. Tiwari A. Imbalance in antioxidant defence and human diseases: Multiple approach of natural antioxidants therapy. Curr Sci 2001;81:1179-87.

2. Gutteridge JM. Free radicals in disease processes: A compilation of cause and consequence. Free Radic Res Commun 1993;19:141-58.

3. Joyce DA. Oxygen radicals in disease. Adv Drug React Bull 1987; $127: 476-9$.

4. Halliwell B. Free radicals, antioxidants, and human disease: Curiosity, cause, or consequence? Lancet 1994; 344: 721-724.

5. Hakiman M, Maziah M. Non enzymatic and enzymatic antioxidant activities in aquous extract of different Ficus deltoidea accessions. J Med Plants Res 2009;3:120-31.

6. Duh PD, Tu YY, Yen GC. Antioxidants activity of aqueous extract of Harnjyur (Chrysanthemum morifolium Ramat). Lebensmwiss Technol 1999;32:269-77.

7. Sundararajan R, Haja NA, Venkatesan K, Mukherjee K, Saha BP, Bandyopadhyay A, et al. Cytisus scoparius link-a natural antioxidant. BMC Complement Altern Med 2006;6:8.

8. Meher R, Rao DM, Reddy KA. Phytochemical screening, antioxidant activity and antimicrobial activity of Spathodea campunalata stem extracts. Int J Phytomed 2015;7:209-18.

9. Brindha BB, Kalaivani K. Evaluation of free radical screening and antioxidant potential of Moringa concanensis nimmo- a medicinal plant used in Indian traditional medication system. Int J Pharm Pharm Sci 2018;10:91-7.

10. Solanki R. Some medicinal plants with antibacterial activity. Int J Comp Pharm 2010;1:10-5.

11. Qusti SY, Abo-khatwa AN, Lahwa MAB. Screening of antioxidant activity and phenolic content of some selected food items cited in the holy Quran. Eur J Bio Sci 2010;2:40-51.

12. Kaur C, Kapoor HC. Antioxidant activity and total phenolic content of some Asian vegetables. Int J Food Sci Tech 2002;37:153-62.

13. Vinson JA, Hao Y, Su X, Zubik L. Phenol antioxidant quantity and quality in foods: Vegetables. J Agri Food Chem 1998;46:3630-4.

14. Wu X, Beecher GR, Holden JM, Haytowitz DB, Gebhardt SE, Prior RL. Lipophilic and hydrophilic antioxidant capacities of common foods in the United States. J Agri Food Chem 2004;52:4026-37.

15. Mundhe KS, Kale AA, Gaikwad SA, Deshpande NR, Kashalkar RV. Evaluation of phenol, flavonoid contents and antioxidant activity of Polyalthia longifolia. J Chem Pharm Res 2011;3:764-9.

16. Trease GE, Evans IC. Text book of Pharmacognosy. $12^{\text {th }}$ ed. London: Bailliere Tindall; 1983. p. 21-2

17. Harborne JB. Phytochemical Methods: A Guide to Modern Techniques of Plant Analysis. London: Chapman and Hall; 1973. p. 49-188.

18. Singleton VL, Rossi JA. Colorimetry of total phenolics with phosphomolybdic-phosphotungtic acid reagent. Am J Enol Viticult 1965;16:144-58

19. Chang CM, Wen YH, Chern J. Estimation of total flavonoid content in 
ropolis by two complementary colorimetric methods. J Food Drug Anal 2002; 10:178-82.

20. Price ML, Butler LG. Rapid visual estimation and spectrophotometric determination of tannin content of sorghum grain. J Agric Food Chem 1977;25:1268-73.

21. Harborne JB. Phytochemical Methods. London: Chapman and Hall, Ltd; 1973. p. 49-188.

22. Van-Burden TP, Robinton WC. Formation of complexes between protein and tannin acid. J Agri Food Chem 1981;1:77-82.

23. Nagata M, Yamashita I. Simple method for simultaneous determination of chlorophyll and carotenoids in tomato fruit. Nippon Shokuhin Kogyo Gakkaish 1992;39:925-28.

24. Prieto P, Pineda M, Aguilar M. Spectrophotometric quantitation of antioxidant capacity through the formation of a phosphomolybdenum complex: Specific application to the determination of vitamin E. Anal Biochem 1999;269:337-41

25. Wong SP, Lai PL, Jen HW. Antioxidant activities of aqueous extracts of selected plants. Food Chem 2006;99:775-83

26. Oyaizu M. Studies on products of browning reaction prepared from glucosamine. Jpn J Nutr 1986;44:307-15.

27. Perez C, Pauli M, Bazerque P. An antibiotic assay by the agar well diffusion method. Acta Biol Med Exp 1990;15:113-5.

28. Shakouie S, Eskandarinezhad M, Mokhtari H, Frough M, Soroush M., Antimicrobial efficacy of AH-Plus, adseal and endofill against Enterococcus faecalis- an in vitro study. Afri J Micro Res 2012;6:991-4.

29. Shahidi BG. Evaluation of antibacterial properties of Iranian medicinal plants against Micrococcus aureus, Serratia marcescens, Klebsiella pneunomiae and Bordella bronchoseptica. As J Sci 2004;3:82-6.

30. Mir MA, Parihar K, Tabasum U, Kumari E. Estimation of alkaloid, saponin and flavonoid, content in various extracts of Crocus sativa. J Med Pl Stud 2016;4:171-4.

31. Ayitey-Smith E, Addae-Mensah I. Phytochemical, nutritional and medical properties of some leafy vegetables consumed by Edo people of Nigeria. W. Afr J Pharma Drug Res 1977;4:7-8.

32. Hernández-Hernández E, Ponce-Alquicira E, Jaramillo-Flores ME, Guerrero Legarreta I. Antioxidant effect rosemary (Rosmarinus officinalis L.) and oregano (Origanum vulgare L.) extracts on TBARS and colour of model raw pork batters. Meat Sci 2009;81:410-7.

33. Gramza A, Khokhar S, Hes M, Jedrusek-Golinska A. Tea extracts influence on catalytical properties of $\mathrm{Fe}^{2+}$ in lipids. Polish J Env Stud 2004; $13: 143$.

34. Shahidi F, Naczk M. Phenolic compounds in fruits and vegetables. In: Phenolics in Food and Nutraceutical. London: CRC LLC; 2004. p. 131-56.

35. Puupponen-Pimiä R, Nohynek L, Alakomi HL, Oksman-Caldentey KM. Bioactive berry compounds-novel tools against human pathogens. Appl
Microbiol Biotechnol 2005;67:8-18.

36. Yao Y, Vieira A. Comparative antioxidant properties of Citrus species: Evidence for potent, non-vitamin antioxidants in C. aurantifolia. Int J F Nutri Public Health 2011;4:108-12.

37. Rohman A, Riyanto S, Yuniarti, Saputra WR, Utami R. Antioxidant activity, total phenolic, and total flavaonoid of extracts and fractions of red fruit (Pandanus conoideus Lam). Int Food Res J 2010;17:97-106.

38. Zheng W, Wang YS. Antioxidant activity and phenolic compounds in selected herbs. J Agri Food Chem 2001;49:5165-70.

39. Chen C, Pearson MA, Gray IJ. Effects of synthetic antioxidants (BHA, BHT and PG) on the mutagenicity of IQ-like compounds. F Chem 1992;43:177-83.

40. Kahl R, Kappus H. Toxicology of the synthetic antioxidants BHA and BHT in comparison with the natural antioxidant vitamin E. Z Lebensm Unters Forsch 1993;196:329-38.

41. Kessler M, Ubeaud G, Jung L. Anti- and pro-oxidant activity of rutin and quercetin derivatives. J Pharm Pharmacol 2003;55:131-42.

42. Cook NC, Samman S. Flavonoids- chemistry, metabolism, cardioprotective effects, and dietary sources. Nutri Biochem 1996;7:66-76.

43. Koleva II, van Beek TA, Linssen JP, de Groot A, Evstatieva LN. Screening of plant extracts for antioxidant activity: A comparative study on three testing methods. Phytochem Anal 2002;13:8-17.

44. Nickavar B, Kamalinejad $M$, Izadpanah $H$. In vitro free radical scavenging activity of five salvia species. Pak J Pharm Sci 2007;20:291-4.

45. Wojdylo A, Oszmianski J, Czemerys R. Antioxidant activity and phenolic compounds in 32 selected herbs. Food Chem 2007;105:940-9.

46. Amarowicz R, Pegg BR, Rahimi-Moghaddam P, Bar B, Weil JA. Freeradical scavenging capacity and antioxidant activity of selected plant species from the Canadian prairies. Food Chem 2003;84:551-62.

47. Ghasemi K, Ghasemi Y, Ebrahimzadeh MA. Antioxidant activity, phenol and flavonoid contents of 13 citrus species peels and tissues. Pak J Pharm Sci 2009;22:277-81.

48. Ghosh G, Subudhi BB, Badajena LD, Ray J, Mishra MK, Mishra SK. Antibacterial activity of Polyalthia longifolia var. Angustifolia stem bark extract. Int J Pharm Tech Res 2011;3:256-60.

49. Gore M, Desai NS. Characterization of phytochemicals and evaluation of anti-cancer potential of Blumea eriantha DC. Physiol Mol Biol Plants 2014;20:475-86.

50. Urmila UT, Supada RR. In vitro antioxidant and in vivo antiinflammatory activity of the aerial part of Blumea eriantha DC. Int $\mathrm{J}$ Pharm Pharma Sci 2018;10:75-9.

51. Khanahmadi M, Rezazadeh SH, Taran M. In vitro antimicrobial and antioxidant properties of Smyrnium cordifolium Boiss. (Umbelliferae) extract. Asian J P1 Sci 2010;9:99-103 